\title{
Phytochemical Complexes Towards Solving Multi-Drug Resistance: An Overview
}

\author{
U Lawal $^{1}$, E E Etim ${ }^{2 *}$ and C Andrew ${ }^{3}$ \\ Department of Chemical Sciences, Federal University Wukari, Nigeria
}

Submission: June 10, 2019; Published: July 03, 2019

${ }^{*}$ Corresponding author: E E Etim, Department of Chemical Sciences, Federal University Wukari, Taraba State, Nigeria

\section{Introduction}

Antimicrobial resistance to therapeutic drugs is already widespread globally and the number is on the rapid increase. Pathogens such as methicillin-resistant Staphylococcus aureus (MRSA) and vancomycin-resistant enterococcus (VRE) and many others are becoming resistant to several established antibiotics [1]. The list of drug resistant pathogens also extends to organisms such as Staphylococcus aureus and enterococcus which are found to be resistant to antibiotics such as oxacillin, penicillin, amoxicillin, methicillin, cephalosporins, gentamicin, erythromycin and trimethoprim, vancomycin, ampicillin, and gentamicin. In addition, gram negative organisms like Escherichia coli, Shigellaflexeneri, Pseudomonas aeruginosa, Salmonella typhi and Gram-positive Bacillus subtilis bacterial strains. Candida albicans, Aspergillus flavus, Fusarium solani, and Candida glaberata are among some fungal pathogens showing resistance feature against established drugs [1].

This new trend of infectious diseases remains worrisome and challenging one due to number of factors such as discoveries of infectious diseases and the increasing number of multi-drug resistant microbes. The appearance of longstanding and novel multi-drug resistance produced in the last years exposed a significant therapeutic want for new classes of antimicrobial drugs despite the numerous numbers of bio-active and other therapeutic drugs obtainable for medicinal use today. Owing to the incessant resistant of some these pathogens towards established known drugs, there is a need to develop novel compounds and complexes that have better antimicrobial properties with a different mode of mechanism compared to the present ones. In other words, developing new anti-pathogenic drugs with a distinct action mechanisms and nano-technological properties will be important in treating bacterial diseases that are known to be drug-resistant.

Cisplatin, a platinum metal-containing drug introduced clinically in 1971 and approved by Food and Drug Administration (FDA) in 1978, is the most effective metal-based anticancer drug in the market till date [2,3]. The tremendous success of cisplatin has encouraged effort in search of more metalbased chemotherapeutic agents in the past few decades $[4,5]$. Recently, the discovery and characterization of new drugs with enhanced activity, selectivity, bioavailability and fewer sideeffects than conventional drugs to treat current diseases is of upmost importance. The steady decrease in the discovery of new antibiotics and commercialization after the 1980s while at the same the serious threat of microbial multi-drug resistance continues to prevail, an example is the increasing occurrence of Methicillin-resistant Staphylococcus aureus (MRSA) over the same period among others [6,7]. On the other hand, is the concern over acquired drug resistance and serious sideeffects of current anti-cancer drugs with rising cases of cancer, breast cancer especially is one of the leading causes of death worldwide, this is one more important reason to develop better antimicrobial alternatives $[4,8]$.

\section{Conclusion}

Several researches and essays have shown the inevitable diversity and potentials of metal complexes for novel design as therapeutic agents [9-11]. The distinct nature of metal centers, unique coordination characters, variable redox states and intrinsic thermodynamic and kinetic properties gives metal complexes potential advantages over organic agents combined [12]. Additionally, Sadler [12] stated that "the ligands not only control the reactivity of the metal but also play critical roles in determining the nature of interactions involved in the recognition of biological target sites such as deoxyribonucleic acid (DNA), enzymes and protein receptors". The enormous interest in research in the field of coordination chemistry with nitrogen and other elements such as sulfur containing ligands such as Schiff bases has been on in recent years [13]. Ternary ligand complexes comprising of amino acids have great potential as biomimetic copies for protein-metal interface. Publications has shown important progress been made in application of trace metal complexes as drugs to deal with numerous human illnesses like, anti-inflammatory, infection control, carcinomas, diabetes and 
neurological disorders [14]. The geometric positioning, nature and number of ligands, metal centers, donor groups, nature of binding is important to knowing their explicit and distinct functional behavior (Stone, et al., 2004). Multi-ligand complexes of threonine and histidine are more in human serum and are significant for blood copper transport Mixed ligand amino acid complexes also play important role in enzymatic inhibition [15]. The main objective behind this overview is to advance the use of transition metal complexes other than platinum in developing new clinical drugs that can be effective in combating pathogens that are resistant to known drugs [16-23].

\section{References}

1. David K Henderson (2009) Controlling the spread of resistant pathogen in intensive care unit. American Journal of Infection Control 34(5): 4654 .

2. Hoeschele J D (2009) Remembrance of Barnett Rosenberg. Dalton Transactions 88(48): 10648-10650.

3. Swarts J C, Cook M J, Baker E N (2008) Metal-containing proteins, macrocycles, and coordination complexes in therapeutic applications and disease. Metal-Based Drugs pp. 180-223.

4. Ronconi L, Fregona D (2009) The Midas touch in cancer chemotherapy: from platinum-to gold-dithiocarbamato complexes. Dalton Transactions 28(48): 10670-10680.

5. Jakupec M A, Galanski M, Arion V B, Hartinger C G, Keppler B K (2008) Antitumour metal compounds: more than theme and variations. DaltonTransactions 14(2): 183-194.

6. Bandow J E, Metzler N N (2009) New ways of killing the beast: Prospects for inorganic-organic hybrid nanomaterials as antibacterial agents. Chembiochem 10(18): 2847-2850.

7. Patra M, Gasser G, Metzler Nolte N (2012) Small organometallic compounds as antibacterial agents. Dalton Transactions, 41(21): 63506358.

8. Pagès J M, Kascàkovà S, Maigre L, Allam A, Alimi M, et al. (2013) New peptide-based antimicrobials for tackling drug resistance in bacteria: Single-cell fluorescence imaging. ACS Medicinal Chemistry Letters 4(6): 556-559.

9. Fricker S P (2007) Metal based drugs: from serendipity to design. Dalton Transactions 21(43): 4903-4917.

10. Haas K L, Franz K J (2009) Application of metal coordination chemistry to explore and manipulate cell biology. Chemical Reviews 109(10) : 4921-4960.
11. Ronconi L, Sadler P J (2007) Using coordination chemistry to design new medicines. Coordination Chemistry Reviews, 251(13-14) : 16331648.

12. Rijt S H, Sadler P J (2009) Current applications and future potential for bioinorganic chemistry in the development of anticancer drugs. Drug Discovery Today 14(23-24): 1089-1097.

13. Pelosi G (2010) Thiosemicarbazone metal complexes: From structure to activity. Open Crystallography Journal 3(1): 16-28.

14. Vulpe C D, S Packman (1995) Cellular copper transport. Annual Review Nutrients (15): 293-300.

15. Farkas E, Enyedy E A, Micera G, E Garribbs (2000) Coordination modes of hydroxamic acids in copper (II), nickel (II) and Zn (II) mixed ligand complexes in aqueous solution. Polyhedron 19(14): 1727-1736.

16. Aliyu H N, Mohammed A S (2012) Synthesis, spectrophotometric and biological activity of nickel (II) and copper (II) complexes with Schiff Base derived from acetyl acetone and histidine. Global Advanced Research Journal of Microbiology 1(5): 067-071.

17. U Lawal, R A Wuana, S I Eneji (2017) Synthesis, Characterization and Antimicrobial Activity of Cu (II), Co (II) and Ni (II) Histidine Complexes. Journal of Natural Sciences Research 7(17): 32-36.

18. Mrozek A, Karolak W J, Kieć Kononowicz K (2003) Five-membered heterocycles, Aromaticity of 1,3-imidazole in $5+n$ hetero-bicyclic molecules. Journal of Molecular Structure 655(3): 397-404.

19. Patra M, Gasser G, Pinto A, Merz K, Ott I, et al. (2009) Synthesis and biological evaluation of chromium bioorganometallics based on the antibiotic platensimycin lead structure. Chem Med Chem 4(11): 19301938.

20. Patra M, Gasser G, Wenzel M, Merz K, Bandow J E, et al. (2012) Sandwich and half-sandwich derivatives of platensimycin: Synthesis and biological evaluation. Organometallics 31(16): 5760-5771.

21. Rijt S H V, Kostrhunova H, Brabec V, Sadler P J (2011) Functionalization of osmium arene anticancer complexes with (poly) arginine: effect on cellular uptake, internalization, and cytotoxicity. Bioconjugate Chemistry 22(2): 218-226.

22. Ronconi L, Marzano C, Zanello P, Corsini M, Miolo G, et al. (2006) Gold (III) dithiocarbamate derivatives for the treatment of cancer: solution chemistry, DNA binding, and hemolytic properties. Journal of Medicinal Chemistry 49(5): 1648-1657.

23. Saeed A, Anvarhusein A I, Saqib Ali, Abdul Rahman A (2006) Perspectives in bioinorganic chemistry of some metal based therapeutic agents. Polyhedron 25(7): 1633-1645.

Your next submission with Juniper Publishers
will reach you the below assets
- Quality Editorial service
- Swift Peer Review
- Reprints availability
- E-prints Service
- Manuscript Podcast for convenient understanding
- Global attainment for your research
- Manuscript accessibility in different formats
( Pdf, E-pub, Full Text, Audio)
- Unceasing customer service
Track the below URL for one-step submission
https://juniperpublishers.com/online-submission.php

